\title{
MEMODIFIKASI PERILAKU ORANG YANG RENTAN
}

\author{
TERHADAP HIV / AIDS
}

\author{
Satrio Budi Wibowo \& Binta Mutiya Rizki \\ Universitas Muhammadiyah Metro \& Universitas Negeri Semarang
}

\begin{abstract}
Pergaulan bebas dan penggunaan narkoba yang marak di Indonesia, menyebabkan semakin pesatnya penyebaran Human Immunodeficiency Virus (HIV) di Indonesia. Pada tahun 2000 jumlah pengidap AIDS naik menjadi 3 kali lipat dan parahnya, trend ini terus berlangsung hingga saat ini. Intervensi yang tepat untuk merubah perilaku rentan penyebab menyebarnya HIV amat dibutuhkan. Intervensi perlakuan dibuat dengan mentargetkan perilaku yang rentan terhadap penyebaran HIV. Perilaku yang menjadi targen dan akan di rubah dalam tulisan ini adalah; a) Perilaku mengkuti tes HIV b) Mengurangi perilaku beresiko penyebab penyebaran HIV c) Mengembangkan pola hidup sehat pada pengidap HIV.
\end{abstract}

Kata Kunci : Intervensi, HIV

Indonesia merupakan Negara urutan keempat dalam hal jumlah populasi pengidap AIDS, Indonesia dijadikan contoh tentang bagaimana epidemic menyebar begitu cepat (Sawitri, dkk. p.578). Awal mula ditemukannnya kasus AIDS di Indonesia adalah pada tahun 1983 penularan dan penyebaran penyakit ini tetap rendah hingga tahun 1999, baru pada tahun 2000 jumlah pengidap AIDS naik menjadi 3 kali lipat dan parahnya, trend ini terus berlangsung hingga saat ini (Sawitri dkk, 2006. p.578). Berdasarkan laporan Ditjen PPM \& PLDepkes RI (Desember, 2008), pada tahun 1999 jumlah total penderita HIV/AIDS masih berjumlah 272 kasus, namun pada tahun 2000 jumlah kasus HIV/AIDS yang ditemukan melonjak menjadi 658 kasus, melonjak hampir 3 kali lipat dalam satu tahun. Pada tahun 2008 jumlah kasus HIV / AIDS yang ditemukan di Indonesia bertambah menjadi sebanyak 5458 orang, melonjak lebih dari 20 kali lipat dibandingkan tahun 1999. Hingga Desember tahun 2008 jumlah total kausu HIV/AIDS yang dilaporkan mencapai 16110 kasus. Lima provinsi terbesar dalam jumlah kasus dilaporkannya HIV/AIDS terdiri dari Jawa barat $17,93 \%$ (2888 kasus), DKI Jakarta $17,26 \%$ (2781 kasus), Jawa Timur 16,08\% (2591 kasus), Papua 14,79\% (2831 kasus), dan Bali 7,31\%(1177 kasus). Penyebaran HIV/ AIDS di Indonesia dapat dilihat pada Gambar 1, dan Gambar 2.

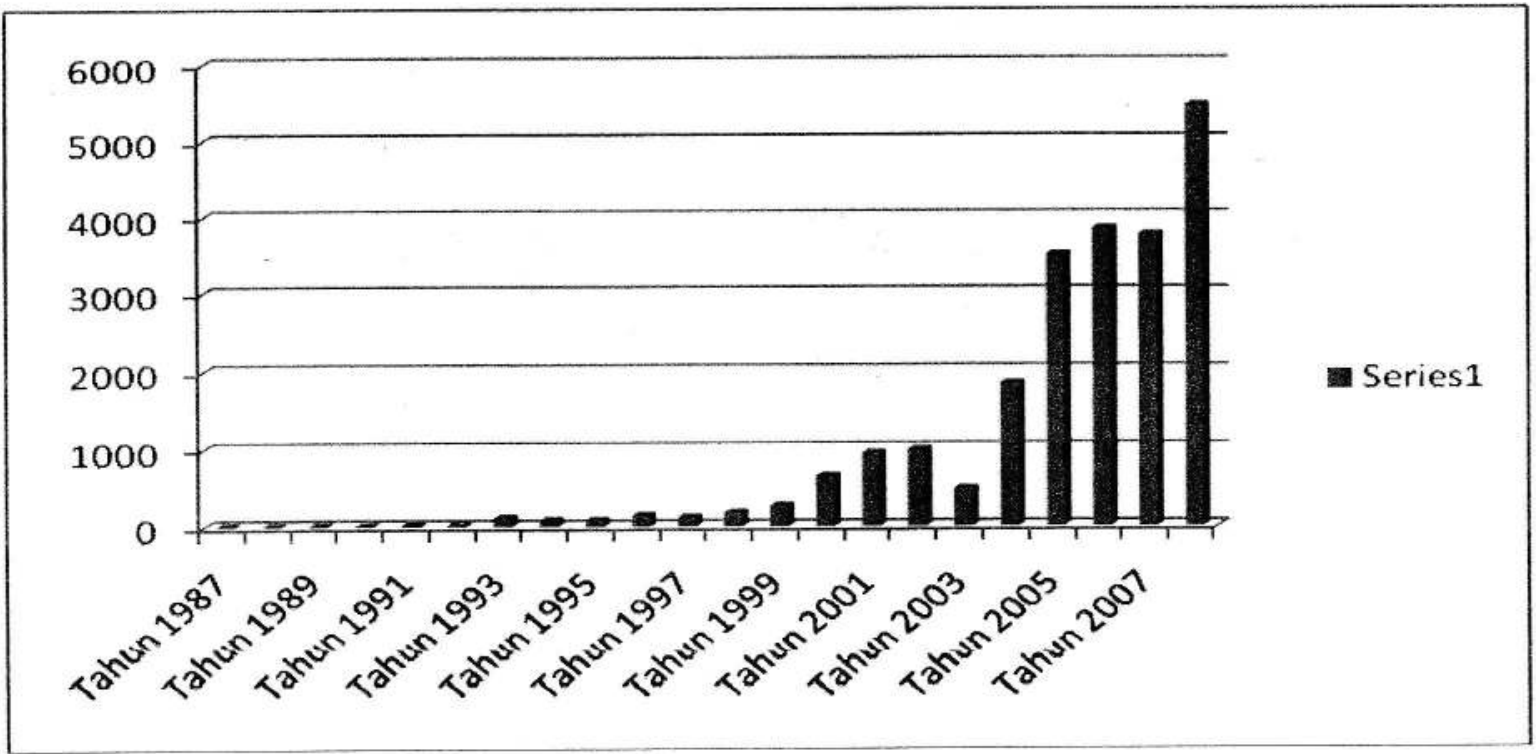

Gambar 1. Jumlah kasus HIV/AIDS tahun 1987 - 2009 (Ditjen PPM \& PL Depkes RI, Januari 2009) 


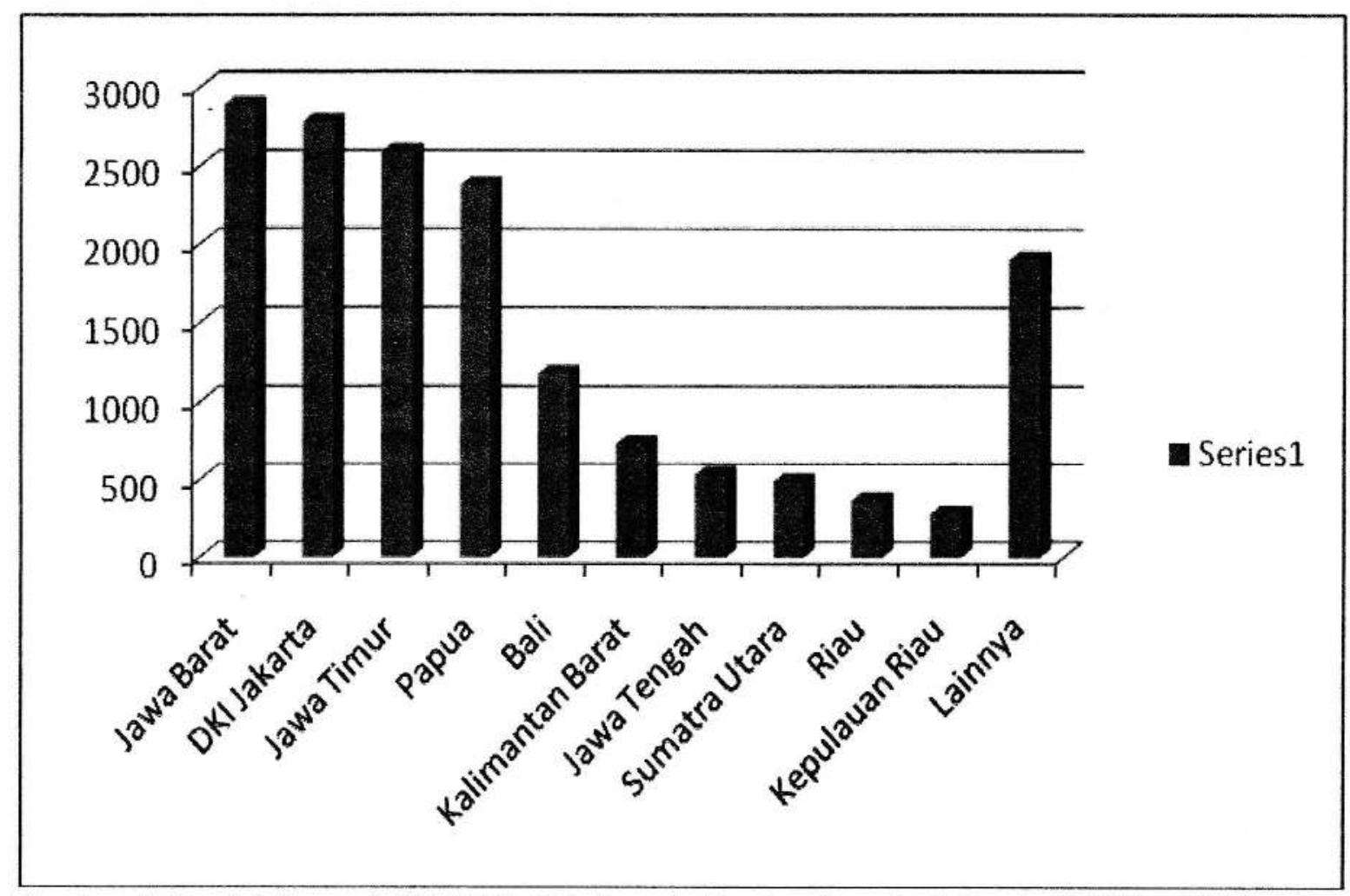

Gambar 2. Jumlah kasus HIV/AIDS di Indonesia Berdasarkan Asal Provinsi (Ditjen PPM \& PL Depkes RI, Januari 2009)

Menurut Sawitri dkk (2006, p.578) berdasarkan data UNAIDS, penyebaran yang begitu cepat di Indonesia dicurigai akibat penggunan suntikan pada para pecandu narkoba, pekerja seks, dan dibeberapa tempat melalui tranfusi donor darah. Data yang diperoleh menunjukkan bahwa kenaikan penyebaran HIV/AIDS melalui jarum suntik sebesar $40 \%$ - 53\% sementara penyebaran melalui pekerja sosial meningkat sebesar $6 \%$ $26 \%$. Pada salah satu pusat rehabilitasi narkoba di Jakarta, pengidap HIV naik dari $15 \%$ di tahun 2000 hingga menjadi lebih dari $40 \%$ di pertengahan tahun 2001. Sedangkan berdasarkan data Ditjen PPM \& PL Depkes RI (2008) penyebab penyebaran HIV/AIDS paling banyak disebabkon oleh hubungan heteroseksual sebanyak 47,98\% (7730 kasus), kemudian 42,28\% (6811 kasus) dikarenakan menggunakan narkoba, 3,78\% (609 kasus) di sebabkan hubungan homoseksual, 3,78\% (609 kasus) tidak diketahui sebabnya, dan $2,18 \%$ (351 kasus) disebabkan transmisi prenatal. Deskripsi data di atas menunjukkan bahwa penyebab utama penyebaran virus HIV diakibatkan oleh penggunaan suntikan pada pengguna narkoba dan hubungan heteroseksual. Penggunaan suntikan pada para pengguna narkoba mengalami kenaikan paling besar sebagai penyebab penyebaran virus HIV. Hampir $90 \%$ kasus baru HIV/AIDS yang dilaporkan pada tahun 2000/2001 diketahui berasal dari injeksi suntikan diantara para pengguna narkoba, dimana di Bali dan jawa, rata-rata penularan $\mathrm{HIV}$ pada pengguna narkoba yang sedang direhabilitasi berkisar dari 10-50\% (Sawitri,dkk, 2006.p.578). Peningkatan jumlah pengguna jarum suntik yang disertai dengan peningkatan HIV lebih sering terlihat pada kotakota besar di Indonesia seperti Jakarta, Bandung, Surabaya, Bali, dan Jogjakarta.

Lebih dari 300.000 orang di deteksi menggunakan narkoba dengan suntikan, dari populasi jumlah penduduk lebih dari 200 juta (Sawitri,dkk, 2006. p.578). Perilaku menyuntik ini biasanya dilakukan oleh pengguna narkoba jenis heroin, buprenorphine, amphetamine-type stimulants (ATS), dextropropoxyphene/ 
proxyvon, dan midazolam tablets. Di Indonesia perilakumenyuntik ini lebih akrab padapengguna heroin walaupun terdapat metode lain dalam menggunakan heroin seperti chasing the dragon (metode dengan menghirup obat yang sebelumnya dibakar dulu di dalam lembaran timah) (Sawitri dkk, 2006).

Perilaku seks bebas yang tidak sehat adalah salah faktor penyebab utama dalam penyebaran virus HIV selain berbagi suntikan, bahkan HIV digolongkan dalam sexually transmitted diseases (STDs). Perilaku seks tidak sehat lebih sering dilakukan oleh para pekerja seks komersial. Para penjaja seks komersil yang melakukan hubungan seks dengan banyak orang menjadi sangat rentan tertular HIV dan sangat potensial menjadi penyebab penyebaran HIV. Tinggkat pendidikan yang rendah diiringi dengan rendahnya pengetahuan pekerja seks tentang cara penyebaran virus HIV, membuat mereka tidak dapat membedakan mana perilaku seks yang aman dan mana yang sangat beresiko menularkan virus HIV. Sehingga penyebaran virus HIV melalui pekerja seks menjadi lebih banyak.

Berdasarkan studi di Asia, penelitian menunjukkan bahwa tumpang tindihnya antara pekerja sex dan penggunaan narkoba jarum suntik dengan proporsi yang substansial bahwa lelaki IDUs membeli seks, pria dan wanita IDUs menujual seks dan pekerja seks yang menggunakan suntikan narkoba menjadi penyebab penyebaran virus HIV (ASEAN, 2007. p.7). Kita mengetahui, bahwa bukanlah menggunakan narkoba, melakukan hubungan seks atau bahkan berbagi suntikan yang menyebarkan HIV, tetapi adanya individu penderita HIV/AIDS yang ikut berbagi suntikan atau menjadi partner dalam berhubungan seks, yang menjadi penyebab penularan virus HIV pada individu yang sebelumnya tidak terkena virus HIV.

Tumpang tindihnya penyebab penyebaran HIV/AIDS dapat disebabkan minimnya pengetahuan masyarakat tentang penyebaran HIV/AIDS serta kesadaran masyarakat yang kurang berpartisipasi untuk mengikuti tes HIV/AIDS. Penularan virus HIV/ AIDS tersebut diakibatkan oleh pola perilaku yang rentan terhadap penularan virus HIV/ AIDS. Perilaku yang rentan ini dilakukan bisa disebabkan karena individu tidak mengetahui bahwa partnernya (dalam berbagi suntikan, atau partner seks) menderita HIV/AIDS, dan penderitapun tidak mengetahui bahwa sebenarnya ia terinfeksi HIV/AIDS. Adanya kesadaran masyarakat untuk berpartisipasi terhadap tes HIV, merupakan titik utama sebelum melakukan intervensi lanjutan, dimana intervensi lanjutan dapat di khususkan pada individu yang positif HIV.

Keikutserttaan masayarakat terutama individu yang rentan terhadap HIV untuk mengikuti tes HIV menjadi hal penting, sebagaai titik awal dalam upaya mengurangi penyebaran HIV, namun, partisipasi masyarakat yang rendah dalam mengikuti tes HIV menjadi kendala dalam upaya mendeteksi individu yang terinfeksi HIV/ AIDS. Berdasarkan hasil interview yang dilakukan oleh Sawitri dkk (2006, p 585) terhadap pengguna narkoba di Bali yang tidak bersedia melakukan tes HIV diketahui bahwa $27,8 \%$ merasa takut akan mendapatkan hasil positif, $27,8 \%$ responden tidak mengetahui ke mana mereka harus pergi untuk melakukan tes HIV, 16,7\% responden dikarenakan tidak mempunyai uang, $16,7 \%$ reponden merasa tidak siap secara mental untuk melakukan tes HIV, dan $16,7 \%$ masih memikirkan apakah akan mengikuti tes atau tidak.

Alasan yang menyebabkan rendahnya partisipasi masyarakat dalam megikuti tes HIV dapat di intervensi dengan menggunakan pendekatan modifikasi perilaku. Modifikasi perilaku dilakukan untuk memunculkan perilaku berpartisipasi mengikuti tes HIV yang diselenggarakan. Setelah mendeteksi individu yang terkena virus HIV, maka pihak kesehatan dapat melakukan upaya pemeliharaan lebih lanjut terhadap individu yang terdeteksi positif 
HIV. Individu yang paling rentan terkena penyakit HIV/AIDS adalah para pengguna narkoba, pelaku seks bebas, dan pekerja seks komersial, sehingga intervensi tahap lanjut akan difokuskan pada pengurangan perilaku berbagi suntikan pada pengguna narkoba, dan peningkatan perilaku seks yang sehat.

Target Intervensi

Target dari intervensi untuk mengurangi penyebaran HIV /AIDS dalam tulisan ini akan terfokus pada perilaku target, subyek intervensi, dan lokasi intervensi. Fokus terhadap target intervensi merupakan upaya pembatasan masalah sehingga permasalahan tidak melebar dan intervensi yang dilakukan lebih terfokus pada perilaku sasaran yang akan di rubah.

\section{Perilaku Target}

Sebagaimana yang telah di jabarakan dalam tulisan awal, bahwa perilaku awal yang ingin dimunculkan dalam intervensi ini adalah kemauan untuk mengikuti tes HIV, baru kemudian fokus pada perilaku beresiko yang rentan tertular HIV / AIDS seperti perilaku berbagi suntikan dan melakukan hubungan seksual. Secara rinci perilaku target yang menjadi fokus dalam modifikasi perilaku dalam tulisan ini adalah:

1. Perilaku mengikuti tes HIV/AIDS pada masyarakat perlu ditingkatkan agar individu yang menderita HIV/AIDS dapat diketahui dan dapat dicegah agar tidak menjadi penyebab menyebarnya Virus HIV/ÄIDS.

2. Tingkat pengetahuan tentang HIV/AIDS perlu ditingkatkan untuk memunculkan kesadaran akan bahaya dan resiko tertular HIV/AIDS.

3. Perilaku menyuntik secara bergantian pada para pengguna narkoba dikurangi atau bahkan dihilangkan, karena perilaku ini salah satu penyebab terbesar menyebarnya virus HIV/AIDS.

4. Perlu diupayakan perilaku-perilaku seks yang sehat yang tidak beresiko menyebarkan HIV/AIDS.
5. Khusus bagi individu yang terdeteksi positif HIV/AIDS ; Menumbuhkan perilaku pemeliharan kesehatan dengan rutin mengikuti pengobatan yang diberikan bagi penderita HIV/AIDS

\section{Subyek Intervensi}

Subyek sasaran dalam program ini adalah individu yang kemungkinan besar mengunakan narkoba, melakukan seks bebas serta wanita pekerja seksual. Secara spesifik berdasarkan data Ditjen PPM \& PL Depkes RI (2008) usia penderita HIV/AIDS terbanyak adalah 20 - 29 tahun (8187 kasus). Sehingga subyek yang akan diberikan intervensi terfokus pada kaum muda.

\section{Lokasi Intervensi}

Berdasarkan defenisi subyek yang akan diintervensi, maka lokasi intervensi dapat dilakukan di sekolah, kampus, lembaga rehabilitasi pengguna narkoba, lembaga pemasyarakatan, diskotik, café, dan tempat berkumpulnya para kaum muda.

\section{Model Intervensi}

Untuk mempromosikan komunitasyang mempunyai resiko tinggi terkena HIV/AIDS dapat menggunakan teknik SABT (Social Action Based-Theory). Di dalam SABT tersebut melibatkan komunitas sosial dalammemodifikasi perilaku masyarakat yang mempunyai resiko tinggi tertular HIV/AIDS. Komunitas yang dilibatkan tidak lain adalah individu-individuyang mempunyai permasalahan yang sama, dalam hal ini sesama individuyang mempunyai resiko tinggi tertular HIV/AIDS. Komponen yang dibutuhkan dalam melakukan promosi tes HIV dapat menggunakan pengaruh teman sebaya, pelatihan manager (mucikari), dan kombinasi antara pengaruh teman sebaya dan manager .

Hasil peneltian Chiao dkk (2008) yang meneliti FCSW (Female Comercial Sex Worker), tes HIV naik scbesar $86 \%$ dari kondisi awal/basicline ( $\mathrm{N}=980$ ) hingga follow up $(\mathrm{N}=903)$ dan secara signifikan terkait dengan 
pengetahuan HIV/AIDS yang tinggi, rendahnya kemungkinan mengidap HIV dan meningkatnya penggunaan kondom. Setelah menilai kondisi social demografi dan menerima variable control, para FCSW dalam kondisi pelatihan manager dan kombinasi teman sebaya/ pelatihan manager secara signifikan terkait secara konsisten dalam penggunaan kondom.

Hasil penelitian Chiao dkk (2008) untuk tes HIV terkait dengan, interval kepercayaan $95 \%$ dalam mendapatkan tes HIV semua model mengontrol pendidikan, gaji perminggu, waktu kerja, dan status partner saat ini. Model 1 menunjukkan peningkatan $86 \%$ di dalam semua tes HIV antara kondisi penelitian baseline dan postline $(\mathrm{AOR}=1.86, \mathrm{p}=0.05)$. Model 2 menambahkan istilah interaksi antara status intervensi dan survey per tahun. Pendidikan teman sebaya dan pelatihan manajer meningkatkan kemungkinan dalam melakukan tes HIV bagi para pekerja seksual/ FCSW. Wanita dalam kelompok pendidikan teman sebaya nilai t empat kali lebih besar kemungkinan dalam melakukan tes HIV dari pada kelompok kontrol (dimana efeknya/ pengaruhnya, $\begin{array}{llll}0.24 & 9 & 16.83\end{array}=$ 4.04).dibandingkan dengan kelompok kontrol, para FCSW dalam kondisi pelatihan manajer kira-kira terlihat 11 kali kemungkinan untuk melakukan tes HIV (efeknya/pengaruhnya 0.03 $9361.07=10.83$ ). sementara disana terdapat perbedaan yang signifikan antar kelompok, namun dalam kelompok kombinasi pendidikan yang dilakukan oleh teman sebaya dan kelompok manajer tidak ada peningkatan yang signifikan dalam melakukan tes HIV.

Model 3 secara progresif menambahkan factor self regulator (misalnya pengetahuan HIV dan menerima control dan penderitaan) terhadap model 2. FCSW dalam pendidikan teman sebaya dan kelompok pelatihan manajer secara signifikan lebih tinggi dalam melakukan tes HIV daripada wanita dalam kelompok control. Kelompok pelatihan manajer/mucikari meningkatkan kemungkinan dalam mendapatkan tes HIV dengan perkiraan $9.36 \mathrm{kali}$ (dimana efek/ pengaruhnya sebesar $0.029467 .84=9.36$ ).

Hasil penelitian Chiao dkk (2008) secara umum tentang FCSW (Female Comersil Sexual Worker) di Filipina menyebutkan bahwa FCSW dengan pengetahuan yang tinggi tentang HIV akan lebih bersedia untuk melakukan tes HIV, dan FCSW yang percaya bahwa tes HIV akan memperkecil resiko mereka untuk tertular HIV secara signifikan lebih bersedia untuk melakukan tes HIV daripada mereka yang menganggap bahwa resiko HIV mereka rendah. FCSW yang berusia lebih tua, mempunyai pendidikan yang baik dan sudah bekerja lama sebagai FCSW akan lebih mudah melakukan tes HIV. FCSW yang mempunyai pasangan/ teman yang tetap dan mempunyai gaji yang lebih tinggi setiap bulan juga mempunyai jumlah yang lebih tinggi dalam melakukan tes HIV. SABT yang sudah pernah dilakukan Chiao dkk tersebut menurut peneliti juga dapat digunakan dalam komunitas yang rantan terkena NARKOBA melalui jarum suntik, seperti diskotik dan sekolah-sekolah.

Selain SABT penulis juga merencanakan program CLEAR yang merupakan intervensi khusus bagi individu yang positif HIV. Sebagaimana SABT, intervensi CLEAR juga didasarkan pada teori perilakukognitif(behavioral-cognitif). Target perilaku yang ingin dirubah pada CLEAR terdiri dari (a) perilaku beresiko yang dapat menyebabkan penularan HIV/AIDS pada orang lain, (b) perilaku setia untuk terus mengikuti pengobatan, dan (c) perilaku untuk meningkatkan kualitas hidup para pengidap HIV.

Alur model intervensi yang akan digunakan untuk mengurangi penyebaran HIV/AIDS dapat di ilustrasikan pada gambar berikut : 


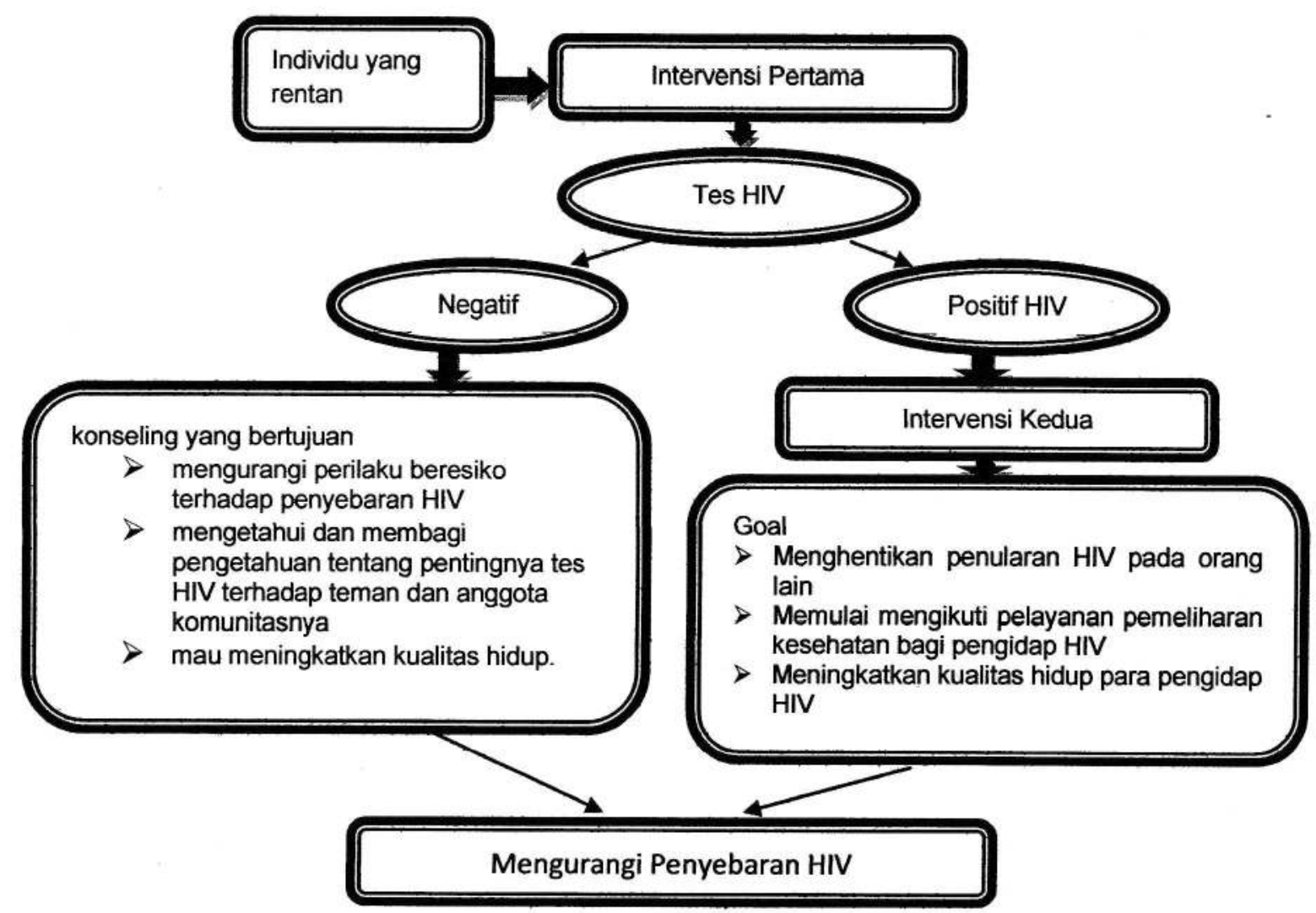

Gambar 3. Alur intervensi

Intervensi awal dilakukan bekerja sama dengan berbagai pihak terkait yang dapat memperlancar proses intervensi (contoh, mucikari saat intervensi dilakukan di tempat pelacuran). Tujuan dari intervensi awal adalah meningkatkan partisipasi individu yang rentan terhadap HIV untuk mengikuti tes HIV. Intervensi diawali dengan melakukan pendekatan terhadap subyek yang rentan terhadap HIV untuk mau mengikuti tes HIV dan menggunakan kondom bagi individu yang bekerja sebagai FCSW. Subjek yang mengikuti tes HIV tidak hanya FCSW tetapi juga individu yang beresiko HIV melalui jarum suntik pada pengguna NAPZA. Program untuk menjalankan aksi tersebut berdasarkan pada SABT (Social Action Based-Theory) dengan melibatkan beberapa individu dalam komunitas setempat sebagai perantara edukasi tentang bahaya HIV dan menyarakan untuk mengikuti tes HIV dan menggunakan kondom.

Intervensi untuk mengajak peran serta masyarakat untuk mengikuti tes HIV tidak hanya sebatas pada pemberian modul intervensi
SABT saja. Pada tempat - tempat yang biasa digunakan oleh individu yang rentan terinfeksi HIV juga dapat diberikan poster-poster yang berisi edukasi yang berkaitan dengan partisipasi mengikuti tes HIV.

Setelah subyekmau menjadi partisipan tes HIV, maka langkah berikut yang dapat dilakukan adalah mengklasifikasikan subyek yang positif HIV dengan subyek yang mendapatkan hasil negatif. Subjek yang ternyata mendaptkan hasil yang negatif diberikan konseling secara kelompok agar mau mengurangi perilaku beresiko terhadappenyebaran HIV, mengetahui dan membagi pengetahuan tentang pentingnya tes HIV terhadap teman dan anggota komunitasnya, dan mau meningkatkan kualitas hidup. Subyek yang mendapatkan hasil positif kemudian diikutkan dalam intervensi modul dua yaitu modul intervensi CLEAR (Choosing Life: Empowerment,Action, Results). Rincianmodul intervensi yang digunakan dalam program ini dapat dijelaskan sebagai berikut: 


\section{Modul pertama}

Promosi tes HIV pada komunitas yang

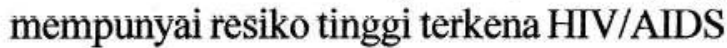
dapat menggunakan teknik SABT (Social Action Based-Theory). Di dalam SABT tersebut melibatkan komunitas sosial dalam memodifikasi perilaku masyarakat yang mempunyai resiko tinggi tertular HIV/AIDS. Komunitas yang dilibatkan tidak lain adalah individu-individu yang mempunyai permasalahan yang sama, dalam hal ini sesama individu yang mempunyai resiko tinggi tertular HIV/AIDS atau individu yang berada di dalam komunitas target. Komponen SABT yang dibutuhkan dalam melakukan promosi tes HIV yang pernah dilakukan oleh Chiao dkk (2008) dalam usahanya memodifikasi perilaku FCSW diFilipinamenggunakan:1.pengaruh/konseling teman sebaya, 2. pelatihan manager (mucikari), dan 3. kombinasi antara pengaruh teman sebaya dan pelatihan manager(mucikari). Tiga metode intervensi tersebut khusus digunakan untuk komunitas pekerja seksual, sedangkan untuk komunitas yang rentan terkena NAPZA melalui jarum suntik dapat juga dilakukan intervensi edukasi melalui Konseling teman sebaya, mèlālùi signnifiān person (gürù, orāng tua, pemimpin organisasi dll).

SABT (Social Action-Based Theory) menawarkan kerangka konsep dan memberikan secara heuristik pedoman intervensi untuk perbaikan (Ewart 1991; Hepworth 2004; Remien et al. 2006). SABT memprediksi perilaku proteksi kesehatan melalui interaksi antara tiga bagian utama: 1 . Kemampuan self regulasi individu; 2 . Konteks lingkungan yang lebih luas dan 3. Respon terhadap keadaan internal afektif.

Unsur/aspek-aspek dalam regulasi diri (self regulation) meliputi factor kognitif dan sikap, seperti pengharapan yang positif akan outcome, pengurangan resiko melalui efikasi diri (self efficacy), persepsi normative, membantu individu yang berresiko untuk mampu menghindar, niat berperilaku untuk menghindari praktek resiko penularan. Dengan penekanan dalam varibel kontekstual, seperti setting dan sumber-sumber enabling, model ini juga menggambarkan perhatian pada bagaimana penyesuaian mereka terhadap perubahan dalam prāktēk kẹsēhātān pribadi. Tes HIV dan penggunaan kondom secara konsisten pada FCSW dapat dihubungkan dengan faktor yang memungkinkan individu tersebut untuk mencari beberapa praktek/perilaku protektifkesehatan dalam konteks yang melingkupi sumber-sumber lingkungan yang positif(Von Lengerke et al. 2004; Weinhardt 2005 dalam Chiao (2008). Sehingga sumber-sumber llingkungan yang positif perlu dikembangakan agar tujuan program dapat tercapai.

Pendekatan konseling teman sebaya menekankan pada pentingnya proses regulasi diri dalam perubahan perilaku melalui teman sebaya. Kelompok pelatihan mucikari/manager pada lingkungan pekerja seksual menekankan pengaruh variable terkait kontex dalam perubahan perilaku. Proses regulasi diri (self regulation) melibatkan faktor kognitif dan sikap individu yang mempunyai resiko tinggi dan variable konteks meliputi pengharapan dukungan berdasarkan norma (supportive normative expectancies) dan kebijakan kesehatan. Juga mempertimbangkan karakteristik social demōografi tertentū terkait dengan perilaku protektif diantara komunitas yang beresiko tinggi terhadap HIV dan pengaruh efek intervensi yang berbeda.

\section{Modul Kedua}

CLEAR (Choosing Life: Empowerment, Action, Results) merupakan salah satu bentuk intervensi yang disusun oleh Lightfoot dkk (2007) yang di adaptasi dari teori behavioral-kognitif dari Ewart. Intervensi CLEAR terdiri dari 3 modul, yang masingmasing berisi enam sesi selama 1,5 jam, jumlah keseluruhan adalah 18 sesi. Modul yang pertama fokus pada intervensi mengurangi penggunaan narkoba, yang kedua mengurangi perilaku-perilaku seks beresiko, dan yang ketiga memelihara kesehatan secara fisik dengan meningkatkan kesetiaan untuk berpartisipasi dalam proses pengobatan. Jabaran masing-masing sesi pada intervensi CLEAR dapat dilihat pada tabel di bawah ini : 


\begin{tabular}{l} 
Modul dalam Intervensi CLEAR \\
\hline Module I: Act Safe-Substance Use \\
1. Identifying My Strengths: Creating a Vision for the Future \\
2. I'm HIV-Positive: Attitudes as Barriers to Future Goals \\
3. Making Commitments: Evaluating and Changing Substance Use \\
4. Seeing the Patterns: Why Do I Use Drugs and Alcohol? \\
5. Beliefs: Thoughts That Influence My Substance Use Patterns \\
6. Future Goals: The Impact of Using Drugs and Alcohol \\
\hline Module 2: Act Safe-Sexual Behaviors \\
1. Higher Self and Sexual Decisions: Facing the Challenges \\
2. Higher Self and Sexual Decisions: Changing Risk Behaviors \\
3. Making Sexual Decisions: Having Safety and Pleasure \\
4. Making Sexual Decisions: Can I Use Condoms (Correctly)? \\
5. Making Sexual Decisions: Can I Influence My Partner to Use Condoms? \\
6. Making Sexual Decisions: How Do I Refuse Unprotected Sex? \\
\hline Module 3: Stay Well: Self-Care/Health Care Behaviors \\
1. Motivation for Change: Wanting to Stay Healthy \\
2. Attending Health Care Appointments \\
3. Participating In Medical Care: Communications and Decision-Making Skills \\
4. Medication Schedules: Can I Stay On Track? \\
5. Medication Schedules: More Tools to Stay on Track \\
6. Maintaining My Progress: Focus on the Future \\
\hline
\end{tabular}

Sebagaimana dijelaskan sebelumnya, dasar konseptual CLEAR adalah teori tindakan sosial (Ewart, 1991). Teori tindakan sosial menjelaskan tindakan aksi proteksi kesehatan sebagai suatu produk dari tiga proses: (a) ketrampilan regulasi diri,(b) konteks lingkungan yang lebih luas yang mempengaruhi proses regulasi diri, dan (c) Respon terhadap keadaan internal afektif.. Di dalam intervensi CLEAR tindakan pemeliharaan kesehatan yang ditargetkan termasuk: (a) menghentikan penularan pada orang lain, (b) Memulai mengikuti pelayanan pemeliharan kesehatan bagi pengidap HIV, dan (c) meningkatkan kualitas hidup. Proses regulasi diri terdiri dari menghadapi dan memanage situasi-situasi dan perilaku-perilaku penuh resiko.

Pihak yang terlibat dalam proses intervensi Proses intervensi yang dilakukan membutuhkan bantuan banyak pihak, terutama adalah pemerintah. Pemerintah diharapkan mampu berperan sebagai motor penggerak dari program yang telah dirancang. Pemerintah diharapkan mampumengkoordinasikan dengan para petugas kesehatan yang berada dibawah kendalinya untuk ikut menjadi bagian rancangan intervensi ini.

Para pekerja sosial, NGO atau relawan yang lain dapat membantu proses sosialisasi pada langkah awal untuk mengajak individu yang rentan terhadap HIV untuk mau berpartisipasi terhadap tes HIV.

\section{Penutup}

Rancangan intervensi dalam tulisan ini bertujuan untuk mengurangi penyebaran HIV/ AIDS, yang membutuhkan keseriusan dari berbagai pihak yang terlibat terutama pemerintah. Karena titik awal intervensi ini adalah mengajak partisipasi masyarakat terutama yang rentan terhadap HIV/AIDS untuk mau mengikuti tes HIV, maka salah satu pilar penyangga kesuksesan rancangan intervensi ini adalah adanya tempat-tempat untuk melakukan tes HIV yang dapat dijangkau dengan mudah oleh masyarakat. Apabila pemerintah bersedia 
menjadikan puskesmas pada tiap Kecamatan atau Kabupaten agar bisa melakukan tes HIV serta memiliki tenaga konselor yang mampu menjalankan intervensi yang telah di rancang, maka diharapkan, intervensi yang dirancang dalam tulisan ini dapat berjalan dengan baik. Jika pemerintah kesulitan menyediakan puskesmas yang mampu melakukan tes HIV serta tenaga konselor pada setiap Kecamatan atau Kabupaten pada seluruh provinsi di Indonesia, maka pihak pemerintah cukup menyediakannya pada provinsi-provinsi yang memiliki populasi penderita HIV yang cukup banyak, seperti pada provinsi Jawa barat, Jakarta, Bali, Papua dan Jawa Timur.

Pihak LSM atau relawan yang bersedia memberikan bantuan terhadap kesuksesan program ini dapat bekerja sama dengan pemerintah. Para pekerja sosial, relawan ataupun LSM dapat ambil bagian pada tugas mengajak masyarakat terutama individu yang rentan tertular virus HIV untuk mau mengikuti tes HIV. Pihak LSM juga dapat berpartisipasi untuk mengadakan tes-tes HIV di tempattempat yang rawan penyebaran virus HIV yang tidak dapat dijangkau oleh puskesmas pemerintah.

\section{Referensi}

ASEAN, 2007. Module; Drug Use and HIV in Asia. http://www.searo. who.int/Link F i l e s/ P u b li c a t i o n s Module_01_Treatment \&_Care_for_HIV_positive_IDUs.pdf

Chiao, Chi; Morisky, Donald E; Ksobiech, Kate; Malow ,Robert M. 2008. Promoting HIV Testing and Condom Use Among Filipina Commercial Sex Workers: Findings from a Quasi-Experimental Intervention Study. Original Paper; AIDS Behav. DOI 10.1007/ s10461-008-9418-9

Sawitri, A. A. Sagung; Sumantera, G. M.; Wirawan, D. N; Ford, K \&; Lehman, E.. 2006. HIV testing experience of drug users in Bali, Indonesia.AIDS Care, August 2006; 18(6): $577 \_588$
Ditjen PPM \& PL Depkes RI. 2008. Statistik Kasus HIV/AIDS di Indonesia Dilapor s/d Desember 2008

Komisi PenanggulanganAIDS Nasional. 2002. Ancaman HIV/AIDS di Indonesia Semakin Nyata, Perlu PenanggulanganLebih Nyata

Lightfoot, M.Rotheram-Borus, M,J. Tevendale, H. 2007. An HIV-Preventive Intervention for Youth Living With HIV. Published by: www.sagepublicatons.com 